\title{
PERAN EKOWISATA DALAM PENGEMBANGAN PARIWISATA BERBASIS MASYARAKAT (STUDI KASUS : HUTAN MANGROVE KUALA LANGSA)
}

\author{
Puti Andiny ${ }^{1 *)}$, Safuridar ${ }^{2)}$ \\ 12) Fakultas Ekonomi Universitas Samudra \\ ${ }^{1 *}$ email: putiandiny@unsam.ac.id \\ 2) email: safuridar@unsam.ac.id
}

\begin{abstract}
Penelitian ini bertujuan untuk mengetahui dan mendeskripsikan karakter produk dan pasar ekowisata yang berbasis masyarakat di kawasan hutan mangrove Kuala Langsa yang dapa digunakan untuk community based ecotourism dan mengkaji sejauh mana ekowisata berpengaruh dalam menggerakan peran serta masyarakat dan memberikan manfaat bagi masyarakat setempat di Kuala Langsa. Data yang digunakan adalah data primer yang diperoleh dari kuisioner yang diberikan kepada 100 orang responden. Data kemudian dianalisis dengan menggunakan analisis statistik deskriptif pada program komputer akan dapat ditampilkan deskripsi statistik berupa nilai rata-rata (mean), simpangan baku (standard devviation) dan frekuensi jawaban untuk setiap variabel. Dari hasil penelitian menunjukan bahwa dari parameter aksesibilitas dan fasilitas yang memberikan dampak positif promosi tentang ekowisata hutan mangrove melalui media sosial dengan mean 3,88 dengan standar deviasinya 0,53711 , sedangkan dampak yang tidak berpengaruh yaitu terdapat festival budaya setempat yang sangat menarik dengan mean 1,19 dengan standar deviasinya 0,39428 . Dari sini terlihat bahwa karakter dan kondisi produk serta pasar ekowisata yang berbasis masyarakat masih kurang memunculkan karakternya.
\end{abstract}

Kata Kunci : Pasar Ekowisata, Community Based Ecotourism. 


\section{PENDAHULUAN}

Indonesia memiliki wilayah pesisir yang sangat luas dan akan menjadi sangat potensial untuk pembangunan wilayah jika dikelola dengan baik. Wilayah pesisir memiliki arti strategis karena merupakan wilayah peralihan antara ekosistem darat dan laut yang dipengaruhi oleh perubahan di darat dan laut. Salah satu sumber daya alam yang cukup penting dalam ekosistem pesisir adalah ekosistem mangrove, Hutan Mangrove adalah tipe hutan yang khas terdapat di sepanjang pantai atau muara sungai yang di pengaruhi oleh pasang surut air laut. Mangrove banyak dijumpai di wilayah pesisir yang terlindung dari gempuran ombak dan daerah yang landai. Mangrove tumbuh optimal di wilayah pesisir yang memiliki muara sungai besar dan delta yang aliran airnya banyak mengandung lumpur. Sedangkan di wilayah pesisir yang tidak bermuara sungai, pertumbuhan vegetasi mangrove tidak optimal. Mangrove sulit tumbuh di wilayah pesisir yang terjal dan berombak besar dengan arus pasang surut kuat, karena kondisi ini tidak memungkinkan terjadinya pengendapan lumpur yang di perlukan sebagai substrat bagi pertumbuhannya (Dahuri, 2013).

Wisata alam merupakan suatu bentuk pemanfaatan sumberdaya alam yang mengutamakan jasa alam untuk kepuasan manusia. Berbagai macam kegiatan wisata yang didukung oleh berbagai fasilitas dan layanan yang disediakan masyarakat, pengusaha, dan pemerintah adalah pariwisata. Ekowisata secara langsung memberikan manfaat bagi lingkungan, budaya dan ekonomi masyarakat lokal. Seorang wisatawan yang melakukan kegiatan wisata berbasis alam hanya dapat pergi mengamati burung saja, namun seorang ekoturis (orang yang melakukan ekowisata) pergi mengamati burung dengan pemandu lokal, tinggal di penginapan yang dimiliki oleh masyarakat lokal dan berkontribusi terhadap ekonomi

masyarakat lokal.

Ambo (2011) mengatakan bahwa, pengembangan ekowisata pesisir dan laut harus mempertimbangkan dua hal, yaitu aspek tujuan wisata dan aspek pasar. Meskipun pengembangan ekowisata menganut konsep pengaruh utama produk atau pasar, namun pengembangan produk wisata tetap menjamin kelestarian sumberdaya alam dan budaya masyarakat pesisir dan laut. Pengembangan ekowisata pesisir dan laut lebih dekat kepada aspek pelestarian karena didalamnya sudah terkandung aspek keberlanjutan. Pelestarian sumberdaya alam dan budaya masyarakat akan menjamin terwujudnya keberlanjutan pembangunan. Dalam pelaksanaannya, ekowisata pesisir dan laut hampir tidak dilakukan eksploitasi sumber daya alam, tetapi hanya menggunakan jasa alam dan masyarakat untuk memenuhi kebutuhan pengetahuan, fisik dam psikologis wisatawan. Bahkan dalam berbagai aspek, ekowisata pesisir dan laut merupakan bentuk wisata yang mengarah ke metatourism. Artinya, ekowisata pesisir dan laut tidak hanya menjual tujuan atau objek, menjual filosofi dan rasa.

Kota Langsa merupakan salah satu Kota di Aceh yang berhasil mengembangkan sektor pariwisata yang juga memiliki ekosistem mangrove. Desa Kuala Langsa yang terletak di pesisir Kecamatan Langsa Barat. Beberapa pihak yang terlibat langsung dalam pemanfaatan ekosistem hutan mangrove diantaranya adalah petambak, pencari ikan, pencari kepiting, pencari udang, pencari kerang, pencari kayu bakar, penyedia kuliner hingga masyarakat secara umum. Agar kegiatan pemanfaatan yang dilakukan di daerah ekosistem mangrove di Desa Kuala Langsa berlangsung secara optimal dan berkelanjutan maka diperlukan suatu perencanaan dan pengelolaan. Keberadaan hutan mangrove di Pelabuhan Kuala Langsa, Kota Langsa, Aceh, telah memberikan dampak yang signifikan pada pertumbuhan dan perkembangan ekonomi masyarakat Langsa.

Menurut data Badan Pusat Statistik Kota Langsa (2015), Kota Langsa memiliki hutan mangrove yang seluas yakni 7.937 Ha. Keberadaan hutan mangorve di Kota Langsa, telah memberikan dampak yang signifikan pada pertumbuhan dan perkembangan ekonomi masyarakat Kota Langsa. Hutan Mangrove yang di lindungi oleh peraturan daerah atau qanun Kota Langsa tersebut, berfungsi sebagai ekowisata bagi masyarakat setempat (Bappeda Kota Langsa, 2012)

Ernawati (2010), mengemukakan Community Based Tourim adalah model manajemen kepariwisataan yang dikelola oleh masyarakat setempat yang berupaya untuk meminimalkan dampak negatif pariwisata terhadap lingkungan dan budaya dan pada saat yang sama menciptakan dampak ekonomi yang positif. Masyarakat tinggal disekitar obyek dan daya tarik pariwisata, sesungguhnya penduduk 
adalah bagian dari atraksi wisata itu sendiri. Konsep pariwisata berbasis masyarakat bermakna bahwa manajemen pariwisata ditempat bersangkutan dikelola oleh masyarakat setempat, ini meliputi pengelolaan kepariwisataan secara menyeluruh dilokasi tersebut, termasuk penyiapan semua produk/pelayanan yang di butuhkan oleh wisatawan. Dengan cara demikian memungkinkan untuk memaksimalkan keuntungan yang diperoleh dari kegiatan kepariwisataan untuk masyarakat setempat, serta menempatkan mereka sebagai subyek kegiatan kepariwisataan bukan sebagai obyek.

\section{TINJAUAN PUSTAKA}

\section{Ekowisata}

Kete (2016) yaitu mendefinisikan ekowisata sebagai bentuk perjalanan wisata ke lokasi yang masih alami dengan tetap mendukung upaya konservasi dan berbasis masyarakat lokal demi terciptanya pembangunan yang berkelanjutan.

Ekowisata merupakan upaya konservasi yang dikemas dalam bentuk lokasi wisata sehingga pengunjung tidak hanya menikmati keindahan ekosistem alami namun juga ikut serta dalam pelestarian lingkungan. Berdasarkan panduan dasar pelaksanaa ekowisata UNESCO, terdapat lima elemen penting yang perlu diketahui oleh setiap pelaku wisata sehingga dapat menjamin pelestarian lingkungan dan peningkatan kesejahteraan masyarakat lokal (kete, 2016) yaitu :

a. Memberikan pengalaman dan pendidikan kepada wisatawan yang dapat meningkatkan pemahaman dan apresiasi terhadap daerah tujuan wisata yang dikunjungi.

b. Memperkecil dampak negatif yang bisa merusak karakteristik lingkungan dan kebudayaan pada daerah yang dikunjungi.

c. Mengikut sertakan masyarakat dalam pengelolaan dan pelaksanaannya.

d. Memberikan keuntungan ekonomi terutama kepada masyarakat lokal, untuk itu kegiatan ekowisata harus bersifat profit (menguntungkan).

e. Dapat terus bertahan dan berkelanjutan. Syukur dkk (2007) menyatakan bahwa pengelolaan mangrove didasarkan atas tiga tahapan yaitu : isu ekologi dan sosial ekonomi, kelembagaan dan perangkat hukum serta strategi pelaksanaan rencana. Isu ekologi meliputi tampak ekologis intervensi manusia terhadap ekosistem mangrove. Berbagai dampak kegiatan manusia terhadap ekosistem mangrove harus di identifikasi baik yang telah terjadi maupun yang akan terjadi di kemudian hari. Dalam hal ini, pengelolaan hutan mangrove terdapat 3 (tiga) komponen yang saling berkaitan yaitu : (1) Potensi sumberdaya hutan mangrove. (2) Masyarakat disekitar hutan mangrove (petani tambak) dan (3) Aparatur pemerintah. Ketiga komponen tersebut merupakan komponen yang dinamis. Sehingga dalam kebijakan pengelolaan mangrove melalui pelibatan masyarakat lebih proaktif kearah pemberdayaan masyarakat dalam bentuk partsipasi.

Partisipasi masyarakat disekitar hutan mangrove mempunyai peranan yang tidak kalah pentingnya bagi kelestarian hutan mangrove. Partisipasi tersebut dapat secara individual maupun kelompok masyarakat. Hal ini sesuai dengan Undang-Undang Nomor 23 Tahun 1997 tentang Pengelolaan Lingkungan Hidup (UU No. 23/1997) Pasal 6 ayat (1) yang berbunyi "setiap orang mempunyai hak dan kewajiban untuk berperan serta dalam rangka pengelolaan lingkungan hidup". Dalam penjelasannya ditegaskan bahwa hak dan kewajiban setiap orang sebagai anggota masyarakat untuk berperan serta dalam kegiatan pengelolaan lingkungan hidup mencakup baik terhadap perencanaan maupun tahap - tahap perencanaan dan penilaian.

\section{Dampak Ekonomi Pariwisata}

Suatu destinasi wisata yang di kunjungi wisatawan dapat di pandang sebagai konsumen sementara. Mereka datang ke daerah tersebut dalam jangka waktu tertentu, menggunakan sumberdaya dan fasilitasnya dan biasanya mengeluarkan uang untuk berbagai keperluan, dan kemudian meninggalkan tempat tersebut untuk kembali kerumah atau negaranya. Jika wisatawan yang datang kedestinasi tersebut sangat banyak, mengeluarkan sebegitu banyak uang untuk membeli berbagai keperluan selama liburannya, tidak dapat di bantah bahwa hal itu akan berdampak pada kehidupan ekonomi daerah tersebut, baik langsung maupun tidak langsung. Dampak ekonomi yang ditimbulkannya dapat bersifat positif maupun negatif (Pitana, 2009) :

1. Dampak positif pariwisata bagi ekonomi

a. Pendapatan dari usaha atau bisnis pariwisata

b. Pendapatan Pemerintah

c. Penyerapan Tenaga Kerja

d. Multiplier effects

2. Dampak negatif pariwisata bagi ekonomi

a. Sifat pariwisata yang musiman,

b. Timbulnya biaya-biaya tambahan lain bagi perekonomian setempat.

\section{Produk Wisata}

Produk ialah suatu produk atau barang diciptakan dan ditawarkan ke pasar untuk dapat memenuhi kebutuhan pasar dan dari produk tersebut pasar atau konsumen mendapatkan kepuasan (Kotler, 2009). 
Menurut Middleton (2001:124) ada tiga komponen utama dari produk wisata, diuraikan sebagai berikut:

1. Atraksi
a. Atraksi wisata Alam,
b. Atraksi wisata buatan Manusia
c. Atraksi Wisata Budaya,
d. Atraksi Wisata Sosial,

2. Amenitas / Fasilitas
a. Akomodasi.
b. Restoran,
b. Transportasi di suatu atraksi,
c. Aktivitas,
d. Fasilitas-fasilitas lain,
e. Retail Outlet,
f. Pelayanan-pelayanan lain,

3. Aksesibilitas
a. Infrastruktur
b. Perlengkapan,
c. Faktor-faktor operasional
d. Peraturan pemerintah

\section{Atraksi Wisata}

Wardiyanta (2006: 52) mengatakan bahwa obyek wisata adalah sesuatu yang menjadi pusat daya tarik wisatawan dan dapat memberikan kepuasaan pada wisatawan. Hal yang dimaksud berupa:1) Berasal dari alam, misalnya pantai, pemandangan alam, pegunungan, hutan, dan lain-lain, 2) Merupakan hasil budaya, misalnya museum, candi, dan galeri, 3) Merupakan kegiatan masyarakat keseharian, misalnya tarian, karnaval, dan lainlain.

Dalam UU. No 10 Tahun 2009 disebutkan "Daya Tarik Wisata adalah segala sesuatu yang memiliki keunikan, keindahan, dan nilai yang berupa keanekaragaman kekayaan alam, budaya dan hasil buatan manusia yang menjadi sasaran atau tujuan kunjungan wisatawan". Jadi dapat disimpulkan bahwa atraksi wisata merupakan sesuatu yang dapat menimbulkan daya tarik bagi wisatawan dan merupakan alasan utama untuk mengunjungi objek dan daya tarik wisata.

\section{Fasilitas Wisata}

Fasilitas wisata ialah pelengkap daerah tujuan wisata yang diperlukan untuk memenuhi kebutuhan dari wisatawan yang sedang menikmati perjalanan wisata. Fasilitas wisata dibuat untuk mendukung konsep atraksi wisata yang sudah ada. Karena itu selain daya tarik wisata, kegiatan wisata yang dilakukan wisatawan membutuhkan adanya fasilitas wisata yang menunjang kegiatan wisata tersebut. Sehingga pada akhirnya setiap komponen saling berkaitan dalam rangkaian wisata perjalanan mulai dari daya tarik wisata, kegiatan wisata, sampai dengan fasilitas wisata merupakan satu kesatuan yang tidak dapat dipisahkan.

\section{Aksesibilitas Wisata}

Aksesibilitas merupakan salah satu faktor yang membantu mempermudah perjalanan wisata para wisatawan yang akan berkunjung ketempat atraksi wisata. Menurut Sammeng (2000:36) Salah satu komponen yang sangat penting dalam kegiatan pariwisata adalah aksesibilitas atau kelancaran perpindahan seseorang dari satu tempat ke tempat lain. Perpindahan tersebut bisa berjarak dekat ataupun berjarak jauh.

Alternatif Pariwisata memiliki dua pengertian yaitu: (Swantoro, 2004)

1. Sebagai salah satu bentuk kepariwisataan yang timbul sebagai reaksi terhadap dampak-dampak negatif dari pengembangan dan perkembangan pariwisata konvensional.

2. Sebagai bentuk kepariwisataan yang berbeda (yang merupakan alternatif) dari pariwisata konvensional untuk menunjang kelestarian lingkungan.

\section{METODE PENELITIAN}

\section{Metode Analisis Data}

Metode analisis data yang digunakan dalam penelitian ini yaitu Analisis Statistik Deksriptif. Dengan menggunakan analisis deskriptif pada program komputer akan dapat di tampilkan deskripsi statistik berupa nilai ratarata (mean), simpangan baku (standard deviation) dan frekuensi jawaban untuk setiap variabel. Analisis ini digunakan untuk mengetahui dan mendeskripsikan karakter produk dan pasar ekowisata berbasis masyarakat mana yang paling berpengaruh dalam menggerakan peran serta masyarakat dan memberikan manfaat bagi masyarakat setempat.

\section{Populasi dan Sampel}

Populasi dalam penelitian ini adalah seluruh penduduk yang berada di sekitar ekosistem mangrove yang berjumlah 35.379 jiwa (Badan Pusat Statistik Kota Langsa, 2017). Adapun metode pengambilan sampel/responden adalah Random Sampling, yaitu pengambilan secara acak.

Sampel merupakan kumpulan dari unit sampling, sampel merupakan subset dari populasi. Penarikan sampel dilakukan dengan menggunakan rumus menurut Notoatmodjoyo (dalam Andiny dan Muslim, 2009) dengan dasar pertimbangan untuk populasi kecil atau lebih besar kecil dari 10.000 dapat menggunakan formula sebagai berikut :

Dimana :

$$
\mathrm{n}=\frac{\mathrm{N}}{1+\mathrm{N}\left(\mathrm{d}^{2}\right)}
$$

$\mathrm{n}=$ besarnya sampel

$\mathrm{N}$ = besarnya populasi

$\mathrm{d}=$ tingkat kepercayaan/ ketepatan yang diinginkan. 


\section{HASIL DAN PEMBAHASAN}

\section{Peran Ekowisata dalam Pengembangan berbasis masyarakat}

Berikut ini adalah pengembangan ekowisata hutan mangrove berbasis masyarakat di Kota langsa:

1. Terdapat Festival Budaya Setempat yang Sangat Menarik

Adanya pengembangan ekowisata hutan mangrove dengan peran masyarakat dalam mempertahankan festival budaya yang dianut dalam kawasan Hutan Mangrove memberikan kesan tersendiri kepada pengunjung yang hadir di kawasan hutan mangrove kuala Langsa. Berdasarkan hasil kuesioner diperoleh responden yang tidak setuju sebanyak 81 orang dengan presentase sebesar $81,0 \%$ dan responden yang kurang setuju sebanyak 19 orang dengan presentase sebesar 19,0\%. Dengan demikian responden yang paling banyak adalah responden yang tidak setuju, karena festival budaya daerah belum diadakan oleh pihak PT. Pelabuhan Kuala Langsa Energi yang bertugas sebagai pengelola ekowisata hutan mangrove sehingga masyarakat tidak terlibat dalam atraksi festival budaya.

2. Terdapat souvenir atau Merchandise yang Berhubungan dengan Objek Wisata

Dengan adanya souvenir yang berhubungan dengan objek wisata maka pengunjung dapat membawa pulang sebagai oleh-oleh khas Kuala Langsa. Berdasarkan hasil kuesioner diperoleh responden yang setuju sebanyak 32 orang dengan persentase sebesar $32 \%$, dan responden yang kurang setuju sebanyak 68 orang dengan persentase $68 \%$. Dengan demikian responden yang paling banyak adalah responden yang kurang setuju, karena souvenir dan merchandise belum ditemukan di pasaran hutan mangrove Kuala Langsa walaupun masyarakat Kuala Langsa memproduksi sendiri hasil dari buah mangrove tersebut akan tetapi masyarakat belum memasarkan hasil dari produksinya sendiri ke objek wisata tersebut.

3. Adanya Keterlibatan Masyarakat Terhadap Pengembangan Atraksi Wisata Baru

Atraksi yang menjadi unggulan Hutan Mangrove baik dalam budaya daerah, kuliner, pertunjukan seni dan lainnya melibatkan masyarakat. Dalam hal ini selalu ada pengembangan atau ide-ide baru guna membuat atraksi yang ada tidak monoton. Berdasarkan hasil kuesioner diperoleh responden yang tidak setuju sebanyak 61 orang dengan presentase sebesar $61,0 \%$, responden yang kurang setuju sebanyak 39 orang dengan presentase sebesar 39,0\%. Dengan demikian responden yang paling banyak adalah responden yang tidak setuju, karena tidak adanya festival budaya serta tidak ada keterlibatan masyarakat setempat dengan itu pengunjung tidak dapat mengetahui serta menambah pengetahuan adat istiadat yang ada khususnya di Kuala Langsa tersebut.

4. Pemandangan Alam Pada Objek Wisata Sangat Indah dan Menarik

Pemandangan alam merupakan keindahan alam yang perlu dijaga dan di lindungi keindahan alamnya, hutan mangrove Kuala Langsa merupakan pemandangan yang eksotis yang harus diketahui berbagai macam pohon, binatang. Berdasarkan hasil kuesioner diperoleh responden yang setuju sebanyak 49 orang dengan persentase sebesar $49 \%$ dan responden sangat setuju sebanyak 36 orang dengan persentase $36 \%$ dan responden sangat setuju sekali sebanyak 15 orang dengan presentase $15 \%$. Dengan demikian responden yang paling banyak adalah responden yang setuju, karena pemandangan alam sangat dicari oleh pengunjung untuk melihat indahnya alam yang ada di hutan mangrove kuala Langsa seperti pemandangan alam yang indah membuat pengunjung menjadi lebih refresh dan dapat menenangkan fikiran karena berada di alam yang asri dan sejuk.

5. Objek Wisata Hutan Mangrove Memberikan Pendidikan Lingkungan Alam

Pendidikan bukan hanya tentang ilmu yang diterima dari suatu lembaga ternama tapi bisa didapatkan dan dipelajari dari mana saja. Pendidikan lingkungan yang diperoleh dari suatu objek wisata memberikan ilmu tentang bagaimana menjaga alam agar tetap asri dan bersih serta memberikan pengajaran bagaimana cara untuk melindungi flora dan fauna agar tidak punah. Berdasarkan hasil kuesioner diperoleh responden yang setuju sebanyak 50 orang dengan persentase sebesar $50 \%$, dan responden sangat setuju sebanyak 38 orang dengan persentase $38 \%$, yang terakhir responden sangat setuju sekali sebanyak 12 orang dengan persentase $12 \%$. Dengan demikian responden yang paling banyak adalah responden yang sangat setuju. Objek wisata Hutan Mangrove kerap sekali memberikan banyak pengetahuan dan pelajaran baru dalam pendidikan lingkungan alam terhadap wisatawan yang berkunjung karena flora dan fauna yang ada serta wisata Hutan Mangrove yang merupakan alam asri dan masih sangat terlindungi membuat wisatawan lebih mengenal alam.

6. Adanya Komitmen Masyarakat Terhadap Perlindungan Alam

Alam merupakan salah satu sumber daya yang terbesar di muka bumi ini tak hanya sebagai sumber daya yang dimiliki tetapi juga sebagai sumber mata pencarain bagi masyarakat memenuhi kebutuhan sehari-harinya. Berdasarkan hasil kuesioner diperoleh responden yang setuju sebanyak 57 orang dengan persentase sebesar $57 \%$, dan responden sangat setuju sebanyak 33 orang dengan persentase 
$33 \%$, yang terakhir responden sangat setuju sekali sebanyak 10 orang dengan persentase $10 \%$. Dengan demikian responden yang paling banyak adalah responden yang setuju. Karena selama ini masyarakat turut serta dalam pemberdayaan lingkungan sekitar Hutan Mangrove seperti penanaman hutan bakau yang di lakukan oleh pemerintah tetapi masyarakat juga berperan dan ikut bergabung dalam hal tersebut.

7. Ekowisata Hutan Mangrove Memiliki Fasilitas yang Lengkap Seperti Tempat Ibadah, Restoran dan Toilet

Tempat ibadah, restoran dan toilet menjadi hal mutlak yang harus ada pada sebuah objek wisata karena banyak wisatawan lokal maupun mancanegara yang akan menggunakan fasilitas tersebut. Berdasarkan hasil kuesioner diperoleh responden yang setuju sebanyak 53 orang dengan persentase $53 \%$, responden yang sangat setuju sebanyak 33 orang dengan persentase $33 \%$, responden yang sangat setuju sekali sebanyak 14 orang dengan persentase $14 \%$. Dengan demikian responden terbanyak adalah responden setuju, karena tempat ibadah yang disediakan sudah tersedia dan memberikan kenyamanan tersendiri bagi wisatawan yang berkunjung. Seperti musholla yang berada di dalam kawasan Hutan Mangrove juga di desain dengan bentuk yang unik dan menunjukkan simbol khas daerah Aceh serta restoran yang memiliki beragama macam kuliner khas Aceh mulai dari mie aceh, rujak aceh, ayam tangkap, mie kepiting dan lain sebagainya.

8. Adanya Fasilitas Akomodasi Seperti Resort dan Losmen di Hutan Mangrove

Resort dan losmen merupakan salah satu fasilitas penting yang harus ada dalam sebuah tempat wisata. Apalagi jika tempat wisata tersebut sudah berkembang dengan sangat maju yang banyak mendatangkan turis lokal maupun mancanegara. Berdasarkan hasil kuesioner diperoleh responden yang tidak setuju sebanyak 37 orang dengan persentase $37 \%$, responden yang kurang setuju sebanyak 63 orang dengan persentase $63 \%$. Dengan demikian responden yang paling banyak adalah responden yang kurang setuju. Penyediaan fasilitas akomodasi seperti resort dan losmen memang belum ada dijumpai di wisata Hutan Mangrove Kuala Langsa.

9. Masyarakat Terlibat dalam Kepemilikan Usaha atau Jasa Layanan Seperti Restoran

Produk perekonomian bukan hanya berupa barang tetapi juga berupa jasa dimana jasa itu sendiri terbagi menjadi beberapa salah satu yang berpengaruh yaitu jasa layanan seperti restoran, dalam hal ini restoran melibatkan masyarakat. Berdasarkan hasil kuesioner diperoleh responden yang setuju sebanyak 12 orang dengan persentase $12 \%$, responden yang sangat setuju sebanyak 65 orang dengan persentase $65 \%$, responden yang sangat setuju sekali sebanyak 23 orang dengan persentase 23\%. Dengan demikian responden terbanyak adalah responden sangat setuju, karena masyarakat sekitar hutan mangrove banyak yang berkecimpung didalam dunia usaha seperti kepemilikan usaha yaitu jasa layanan seperti restoran yang ada didalam Hutan Mangrove dan di sepanjang jalan hutan mangrove terdapat restoran yang menyediakan kuliner khas daerah tersebut seperti mie aceh, rujak aceh, ayam tangkap, mie kepiting dan lain sebagainya.

10. Objek Wisata Hutan Mangrove Memiliki Pengawasan Terhadap Flora dan Fauna yang ada di Sekitar

Objek wisata merupakan sebagai nilai jual tersendiri bagi suatu wisata. Untuk itu, dibutuhkan adanya pengawasan atau penjagaan khusus di dalam objek wisata agar para wisatawan merasa nyaman dan tidak terganggu dalam menikmati keindahan objek wisata tersebut. Berdasarkan hasil kuesioner diperoleh responden yang setuju sebanyak 58 orang dengan presentase $58 \%$, responden yang sangat setuju sebanyak 34 orang dengan presentase $34 \%$, responden yang sangat setuju sekali sebanyak 8 orang dengan presentase $8 \%$. Dengan demikian responden yang paling banyak adalah responden yang setuju, karena PT. Pelabuhan Kuala Langsa Energi telah memberikan tugas kepada Polisi Hutan untuk pengawasan dan penjagaan terhadap objek wisata yang ada agar binatang-binatang atau fauna yang ada tidak menggagu wisatawan.

11. Adanya peningkatan dan perbaikan kualitas fasilitas umum dan jaringan infrastruktur yang dapat dinikmati oleh masyarakat

Fasilitas umum dan jaringan infrastruktur menjadi pemicu dalam mendorong berkembangnya suatu daerah atau seperti menjadi salah satu faktor pendukung dalam daya tarik suatu daerah apalagi adanya peningkatan dan perbaikan dalam kualitas fasilitas umum jaringan infrastruktur tersebut. Berdasarkan hasil kuesioner diperoleh responden yang setuju sebanyak 72 orang dengan presentase $72 \%$, responden yang sangat setuju sebanyak 28 orang dengan presentase $28 \%$, Dengan demikian responden yang paling banyak adalah responden yang setuju. Hal ini karena fasilitas umum disepanjang jalan menuju hutan mangrove selalu mengalami perbaikan dan peningkatan dari tahun sebelumnya dan jaringan infrastruktur yang tersedia juga sudah mengalami perkembangan.

12. Jalan Menuju Lokasi Ekowisata Hutan Mangrove Tersedia dan Mudah di Tempuh

Jalan akan memberikan kemudahan bagi pengguna jalan untuk menuju tempat yang 
dinginkannya. Berdasarkan hasil kuesioner diperoleh responden setuju sebanyak 72 orang dengan persentase $72 \%$, responden sangat setuju sebanyak 21 orang dengan persentase sebanyak $21 \%$ dan responden sangat setuju sekali sebanyak 7 orang dengan persentase $7 \%$. Dengan demikian responden terbanyak adalah responden setuju, jalan menuju hutan mangrove mudah ditempuh bagi wisatawan serta masyarakat yang ingin menuju hutan mangrove karena fasilitas jalan yang tersedia dalam kondisi sedang dan baik.

13. Tersedianya Petunjuk Jalan Sepanjang Ekowisata Hutan Mangrove

Petunjuk jalan menjadi pedoman dan pemberi arah agar memudahkan wisatawan dan masyarakat yang ingin menuju hutan mangrove. Berdasarkan hasil kuesioner diperoleh responden setuju sebanyak 36 orang dengan persentase $36 \%$, responden sangat setuju sebanyak 53 orang dengan persentase sebanyak $53 \%$, responden sangat setuju sekali sebanyak 11 orang dengan persentase $11 \%$. Dengan demikian bahwa responden terbanyak adalah responden sangat setuju, karena petunjuk jalan menuju hutan mangrove sudah banyak tersedia dan juga sangat membantu wisatawan dan masyarakat yang ingin menuju hutan mangrove.

14. Adanya Sarana Transportasi Umum Yang Mudah di Dapat Ekowisata Hutan Mangrove

Transportasi merupakan suatu benda bergerak yang digunakan untuk membawa atau memindahkan seseorang ketempat tujuannya. Sarana transportasi harus ada pada setiap tempat wisata guna memudahkan wisatawan untuk menuju objek wisata. Berdasarkan hasil kuesioner diperoleh responden yang setuju sebanyak 72 orang dengan persentase $72 \%$ dan responden sangat setuju sebanyak 28 orang dengan persentase $28 \%$. Dengan demikian terlihat bahwa responden terbanyak adalah responden setuju, sebab banyak wisatawan yang merasa mudah untuk menuju tempat wisata karena banyaknya transportasi yang tersedia untuk menuju tempat wisata.

15. Keterlibatan Masyarakat Dalam Penyediaan Jasa Angkutan Umum

Jasa angkutan umum merupakan sebuah transportasi yang disediakan oleh pemerintah kota atau masyarakat sekitar sendiri yang berkecimpung atau bermata pencaharian dibidang tersebut. Berdasarkan hasil kuesioner diperoleh responden tidak setuju sebanyak 27 orang dengan persentase $27 \%$ dan responden kurang setuju sebanyak 68 orang dengan persentase $68 \%$ dan terakahir responden setuju sebanyak $5 \%$ orang dengan presentase $5 \%$. Dengan responden terbanyak kurang setuju, hal ini karena masyarakat sekitar hutan mangrove hampir rata-rata bermata pencaharian sebagai nelayan dan pariwisatawan yang berkunjung rata-rata mereka menggunakan transportasi milik mereka sendiri jadi jarang ditemui, jika pun ada transportasi yang di temui seperti becak tetapi tidak dominan melibatkan peran masyarakat sekitar hutan mangrove

16. Pengembangan Sarana dan Prasaran Ekowisata Hutan Mangrove Melibatkan Masyarakat Setempat

Pengembangan sarana dan prasarana objek wisata harus dilakukan guna mengembangkan dan menggali lagi potensi objek wisata tersebut. Apalagi dengan melibatkan masyarakat setempat dapat membuat objek wisata asri dengan keindahan alamnya dan membuat masyarakat juga memahami kewajibannya. Berdasarkan hasil kuesioner diperoleh responden terbanyak adalah responden setuju sebanyak 69 orang dengan persentase $69 \%$ dan responden sangat setuju sebanyak 22 orang dengan persentase $22 \%$ dan terakahir responden sangat setuju sekali sebanyak $9 \%$ orang dengan presentase 9\%. Dengan demikian responden terbanyak adalah responden setuju, karena masyarakat sudah berperan dan ikut andil dalam pengembangan sarana dan prasarana objek wisata Hutan Mangrove, seperti adanya perbaikan atau penambahan tempat untuk menikmati destinasi wisata yang dilakukan selama ini dibantu oleh masyarakat juga.

17. Adanya Promosi Tentang Ekowisata Hutan Mangrove Melalui Media Sosial Berdasarkan hasil kuesioner diperoleh responden terbanyak adalah responden setuju sebanyak 21 orang dengan persentase $21 \%$ dan responden sangat setuju sebanyak 70 orang dengan persentase $70 \%$ dan terakahir responden sangat setuju sekali sebanyak $9 \%$ orang dengan presentase $9 \%$. Dengan demikian responden terbanyak adalah responden sangat setuju. Karena Kota Langsa lebih konsisten kembangkan wisata daerah dan hal ini sesuai apa yang ada diwisata hutan mangrove Kuala Langsa bahwasannya sudah banyak dilakukan promosi dari media sosial mulai dari instagram, facebook dan lain sebagainya.

\section{PEMBAHASAN}

\section{Peran Ekowisata dalam Pengembangan Pariwisata Berbasis Masyarakat di Hutan Mangrove Kuala Langsa}

Peran ekowisata dalam pengembangan pariwisata berbasis masyarakat dapat diketahui dari hasil kuisioner yang diberikan kepada responden. Data tersebut berupa data parameter dari variabel pada penelitian ini yang dirasakan masyarakat Kuala Langsa atau masyarakat sekitar wisata Hutan Mangrove. Parameter tersebut akan disajikan nilai rata-rata dari hasil jawaban responden dimana data tersebut dianalisis menggunakan SPSS, nilai rata-rata dapat dilihat pada tabel berikut ini : 
Paramater ekowisata berbasis masyarakat yang paling sangat memberikan manfaat positifnya adalah : Terdapat festival budaya setempat yang sangat menarik mean sebesar 1,19 dengan standar deviasi 039428, terdapat souvenir atau merchandise yang berhubungan dengan objek wisata mean 1,72 dengan standar deviasi 0,53333 , adanya keterlibatan masyarakat terhadap pengembangan atraksi wisata baru mean 1,39 dengan standar deviasi 0,49021, pemandangan alam pada objek wisata sangat indah dan menarik mean 3,66 dengan standar deviasi 0,72780, ekowisata hutan mangrove memberikan pendidikan lingkungan mean 3,62 dengan standar deviasi 0,69311, adanya komitmen masyarakat terhadap perlindungan alam mean 3,53 dengan standar deviasi 0,67353. Analisis selanjutnya yaitu analisis ekowisata hutan mangrove memiliki fasilitas yang lengkap seperti tempat ibadah, restoran dan toilet mean 3,61 dengan standar deviasi 0,72328, adanya fasilitas akomodasi seperti resort dan losmen di hutan mangrove mean 1,63 dengan standar deviasi 0,48524, masyarakat terlibat dalam kepemilikan usaha atau jasa layanan seperti restoran mean 2,11 dengan standar deviasi 0,58422 , objek wisata hutan mangrove memiliki pengawasan terhadap flora dan fauna yang ada disekitar mean 3,50 dengan standar deviasi 0,64354 , adanya peningkatan dan perbaikan kualitasfasilitas umum dan jaringan infrastruktur yang dapat dinikmati oleh masyarakat mean 3,28 dengan standar deviasi 0,45126 dan jalan menuju lokasi ekowisata hutan mangrove tersedia dan mudah di tempuh mean 3,35 dengan standar deviasi 0,60927

Selanjutnya tersedianya petunjuk jalan disepanjang ekowisata hutan mangrove mean 3,75 dengan standar deviasi 0,64157, adanya sarana transportasi umum yang mudah didapat ekowisata hutan mangrove mean 3,28 dengan standar deviasi 0,45126 , keterlibatan masyarakat dalam penyediaan jasa angkutan umum mean 1,78 dengan standar deviasi 0,52378, pengembangan saran dan prasarana ekowisata hutan mangrove melibatkan masyarakat setempat mean 3.40 dengan standar deviasi 0,65134 , adanya promosi tentang ekowisata hutan mangrove melalui media sosial mean 3,88 dengan standar deviasi 0,53711

Nilai mean tertinggi adalah adanya promosi tentang ekowisata hutan mangrove melalui media sosial, ini karenakan pemerintah Kota Langsa sendiri memang lebih unggul di jasa pariwisata dan hal ini sesuai apa yang ada diwisata hutan mangrove Kuala Langsa, bahwasannya sudah banyak dilakukan promosi dari media sosial mulai dari instagram, facebook dan lain sebagainya tentang destinasi wisata hutan mangrove Kuala Langsa sehingga akan banyak para wisatawan yang akan lebih mengetahui tentang hutan mangrove.
NIAGAWAN Vol 8 No 2 Juli 2019

Dengan demikian dapat diketahui bahwa peran ekowisata dalam pengembangan pariwisata ini sudah berbasis masyarakat. Dengan adanya ekowisata hutan mangrove masyarakat dapat merasakan dampak secara langsung maupun tidak langsung. Dari hal ini dapat diketahui bahwa keberadaan hutan mangrove dapat memberikan dampak yang cukup positif kepada masyarakat Kuala Langsa dan Kota Langsa.

\section{KESIMPULAN DAN SARAN}

Berdasarkan hasil penelitian dan pembahasan, maka penulis mengambil beberapa kesimpulan sebagai berikut: (1) Secara umum peran ekowisata dalam pengembangan pariwisata berbasis masyarakat ini dapat dilihat bahwa sudah didominasi oleh parameter atraksi, aksesibilitas dan fasilitas yang memberikan dampak positif terhadap masyarakat yaitu promosi tentang ekowisata hutan mangrove melalui media sosial dengan mean 3,88. Dari ini terlihat bahwa karakter dan kondisi produk serta pasar ekowisata yang berbasis masyarakat masih kurang memunculkan karakternya dan untuk kondisi sudah mencapai sekitar $75 \%$ dalam keadaan baik. (2) Peran ekowisata juga sudah sangat dirasakan masyarakat sekitar. Karena sudah banyak para wisatawan dari luar daerah yang pernah mengunjungi objek wisata tersebut. Selain itu, dengan adanya ekowisata ini membuat masyarakat lebih berperan aktif dan ikut serta dalam pengembangan pariwisata yang ada.

\section{REFERENSI}

Ambo Tuwo. 2011. Pengelolaan Ekowisata Pesisir dan Laut. Surabaya: Brilian Internasional

Badan Perencanaan Pembangunan Daerah Kota Langsa [BAPPEDA]. 2012 Langsa

Badan Pusat Statistik Kota Langsa [BPS]. 2015 Statistik Daerah Kota Langsa.

Badan Pusat Statistik Kota Langsa [BPS]. 2016 Statistik Daerah Kota Langsa.

Badan Pusat Statistik Kota Langsa [BPS]. 2017 Statistik Daerah Kota Langsa.

Badrudin, 2001. Pengantar Pariwisata. Jakarta: Melnish

Dahuri R, J. Rais, P. Ginting dan M.J. Sitepu. 2001. Pengelolaan Sumberdaya wilayah Pesisir dan Laut Terpadu. Pradya Paramita : Jakarta.

Ernawati, Ni Made. (2010). Tingkat kesiapan desa sebagai tempat wisata berbasis 
masyarakat. Bali : Politeknik Negeri Bali.Jurnal Analiss Pariwisata Vol.10.

Fandeli, C dan Mukhlison. 2000. Pengusahaan Ekowisata. Fakultas Kehutanan Universitas Gadjah Mada bekerja sama dengan unit KSDA Daerah Istimewah Yogyakarta dan Pustaka Pelajar, Yogyakarta.

Giampicolli dan Kalis, 2012. Community-based tourism and local culture: the case of the amaMpondo. Journal. North-West University (South Africa)

Hainsworth, D. 2009 "Community Tourism and Broad-based Local Development: The Case of Doi Village, Thua Then province, Vietnam". In Tourism and community development. Asian practices. Madrid: World Toruism Organization.

Kepe, T. and Cousin, B. 2000. "Resource tenure and power relations in community wildlife contexts: the case of the Mkambati area on the Wild Coast of south Africa". Evaluating Eden Series. Discussion Paper No.16. International Institute for Environment and Development: London.

Kete, S.C.R. 2016. Pengelola Ekowisata Berbasis Goa :Wisata Alam Goa Pindul. Yogyakarta : DeePublisher

Kotler, Philip, Jhon T.Brown, James C Makes (2009:304). Marketing for Hospitality and Tourism. Prentice Hall.

Lopez-Guzman dkk, 2011. "Community- Based Tourism In Developing Countries: A Case Study". Journal. University of Córdoba (Spain).

Majid, Petana Lesmana. 2013. Studi Potensi Ekowisata Mangrove di Kuala Langsa Provinsi Aceh. Jurnal. Manajemen Sumberdaya Perairan. Fakultas Pertanian. Universitas Sumatera Utara.

Middleton, Victor TC \& Jackie Clarke. 2001. Marketing in Travel and Tourism $3 r^{d}$ Edition. Butterworth-Heinemann: Oxford

Mill, Robert Christie. 2000. Tourism The International Business. Jakarta: PT Raja Grafindo Persada.

Muallisin, Isnaini. 2007. Model Pengembangan Pariwisata Berbasis Masyarakat di Kota Yogyakarta. Yogyakarta: Jurnal Penelitian BAPPEDA Kota Yogyakarta.

Muhammad Yusuf. 2012. Ilmu Ekonomi

Regional. Medan: Perdana Publishing.
NIAGAWAN Vol 8 No 2 Juli 2019

Pitana I Gde, Diarta I Ketut Surya. 2009. Pengantar Ilmu Pariwisata. Jakarta: Penerbit Andi.

Poerwanto,R. 2004. Pembangunan Sentra Produksi Buah berbasis Mutu. Penebar Swadaya. Jakarta.

Ridwan, Mohammad. (2012), Perencanaan dan Pengembangan Pariwisata. PT SOFMEDIA: Medan.

Sammeng, A.M., 2000, Cakrawala Pariwisata, Jakarta: Balai Pustaka.

Suparmako, M, 2014. Ekonomi sumberdaya alam dan lingkungan. Yogyakarta: BPFE Yogyakarta.

Suwantoro, Gama, 2004. Dasar-dasar Pariwisata. Penerbit Andi Yogyakarta

Syahid, Ahmad rosyidi. 2015. Studi Pariwisata : pusat referensi ilmu pariwisata.

Syukur Djazuli, Aipassa dan Arifin. 2007. Analisis Kebijakan Pelibatan Masyarakat dalam mendukung Pengelolaan Hutan Mangrove di Kota Bontang. Jurnal Hutan dan Masyarakat. Vol. 14. N0. 2 Desember 2007.

Wardiyanta, 2006. Metode Penelitian Pariwisata, Yogyakarta : ANDI

Yulianda, F. 2007. Ekowisata Bahari Sebagai Alternatif Pemanfaatan Sumberdaya Pesisir Berbasis Konservasi. Makalah. Departemen Manajemen Sumberdaya Perairan. Fakultas Perikanan dan Ilmu Kelautan. Institut Pertanian Bogor. Bogor.

Zorn, E. \& Farthing, L.E. (2007). Communitarian tourism. Hosts and mediators in Peru. Annals of Tourism Research, Vol. 34, No.3, pp.673-689. 